Крутов В. В., д.ю.н., професор ${ }^{1}$;

Яїчко О. М. ${ }^{2}$

1 - Український союз промисловців і підприємців, Київ;

2 - Національна академія Державної прикордонної служби України імені Богдана Хмельницького, Хмельницький

\title{
Методика роботи штабу прикордонного загону з організації використання мобільного підрозділу
}

Резюме. У статті, на основі проведеного аналізу існуючої нормативно-правової бази щодо організації та управління оперативно-службовою діяльністю мобільних підрозділів та досвіду роботи штабів прикордонних загонів, викладені пропозиції до методики роботи штабу прикордонного загону 3 організації використання мобільного підрозділу .

Ключові слова: мобільний підрозділ, методика, аналіз керівних документів та досвіду.

Постановка проблеми. За роки існування мобільних підрозділів Державної прикордонної служби (далі Держприкордонслужби) прикордонники здобули неабиякий досвід та водночас виявили у своїй роботі низку питань, що потребують удосконалення. Тож, наразі, одним iз найголовніших завдань $\epsilon$ реформування підрозділів спеціального призначення.

У складних соціально-економічних i військово-політичних умовах сьогодення, які характеризують динамічну ситуацію на державному кордоні, актуалізується проблема пошуку принципово нових підходів до організації та управління оперативнослужбовою діяльністю мобільних підрозділів, професійної підготовки підлеглого персоналу.

Аналіз останніх досліджень i публікацій. Проведено аналіз наявних матеріалів, які висвітлюють досвід використання мобільних підрозділів та керівних документів Державної прикордонної служби України, що визначають порядок організації їх використання в оперативнослужбовій діяльності.

Мета статті. На основі проведеного аналізу існуючої нормативно-правової бази організації та управління оперативнослужбовою діяльністю мобільних підрозділів та досвіду роботи штабів прикордонних загонів щодо організації їх використання викласти методику роботи штабу прикордонного загону 3 організації використання мобільного підрозділу в ході оперативно-службових дій.

Виклад основного матеріалу. Оперативно-службова діяльність мобільних підрозділів є складним процесом та припускає вплив як об'єктивних, так і суб'єктивних факторів. Під час розроблення методики роботи штабу прикордонного загону 3 організації їх використання необхідно враховувати такі фактори, як невизначеність та різноманітність умов, в яких здійснюють оперативно-службову діяльність мобільні підрозділи.

Під методикою роботи штабу прикордонного загону 3 організації використання мобільного підрозділу в оперативно-службовій діяльності розуміється сукупність методів, прийомів, способів, що дають змогу досягти поставленої мети. Методика, з одного боку, повинна грунтуватися на наукових принципах управління, 3 іншого враховувати знання і досвід керівників.

У широкому сенсі слова під методом розуміються прийоми і способи, за допомогою яких виявляється дія на керовані об'єкти 3 метою практичного здійснення завдань. Термін "метод" означає підхід, спосіб, дію, процес, прийом, процедуру, правило, техніку.

Арсенал методів великий i різноманітний. Тому головне полягає в умінні визначити необхідність i доцільність використання найбільш раціонального 3 них.

Запропонована методика представлена як послідовність етапів, операцій та процедур, між якими існує прямий зв' язок.

Призначення методики - допомогти відповідним начальникам (органам управління) у будь-яких умовах обстановки досягти мети оперативно-службової діяльності мобільного підрозділу.

При розробленні методики враховувалось, що вона повинна відповідати вимогам, які виходять 3 умов i специфіки самого процесу оперативно-службової діяльності. Тому, з огляду на творчий характер 
цього процесу, до методики висунуті такі вимоги:

відповідність законам діалектичного мислення, теорії пізнання, логіці, законам $i$ принципам управління - начальник (орган управління) повинен володіти методами мислення, умінням досліджувати проблеми, організовувати свою інтелектуальну діяльність i роботу персоналу, який залучається до оперативно-службових дій;

універсальність $і$ гнучкість -
характеристика придатності методики в будьяких умовах обстановки і сферах діяльності - мета методики в даному випадку є озброєння відповідного начальника (органа управління) науковими методами мислення i найбільш раціональними способами організації своєї роботи, що надає можливість виявити творчі здібності у виборі оптимального варіанта дій під час оперативно-службової діяльності;

nростота $i$ ясність, що дають змогу порівняно легко і швидко засвоїти методику всіма керівниками (органами управління).

Загальний задум методики. У запропонованій методиці виділено чотири основних блоки, які наведено у табл. 1.

Таблиця 1
Основні заходи етапу

\begin{tabular}{|c|c|}
\hline Номер та назва етапу & Сутність етапу \\
\hline $\begin{array}{c}\text { Перший етап: } \\
\text { “Планування } \\
\text { оперативно-служсбової } \\
\text { діяльності мобільного } \\
\text { підрозділу" }\end{array}$ & \begin{tabular}{lcr} 
Комплекс & заходів \\
вироблення & рішення \\
використання & \multicolumn{2}{c}{ мобільного } \\
підрозділу, & способів \\
послідовності & дій \\
досягнення визначеної мети
\end{tabular} \\
\hline $\begin{array}{c}\text { Другий етап: } \\
\text { “Організація } \\
\text { оперативно-служсбової } \\
\text { діяльності мобільного } \\
\text { підрозділу” }\end{array}$ & $\begin{array}{lr}\text { Комплекс } & \text { заходів } \\
\text { організації } & \text { виконання } \\
\text { рішення на } & \text { використання } \\
\text { мобільного підрозділу }\end{array}$ \\
\hline $\begin{array}{c}\text { Третій етап: } \\
\text { “Контроль } \\
\text { готовності до } \\
\text { оперативно-служсбової } \\
\text { діяльності" }\end{array}$ & 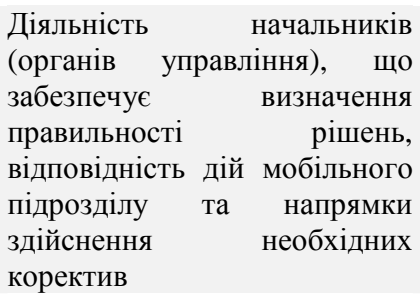 \\
\hline $\begin{array}{c}\text { Четвертий етап: } \\
\text { “Практична робота } \\
\text { на визначеній ділянці" }\end{array}$ & \begin{tabular}{lrr} 
Діяльність & \multicolumn{2}{c}{ начальників } \\
(органів управління) щодо \\
підготовки дій & мобільного \\
підрозділу & до дій \\
місцевості & &
\end{tabular} \\
\hline
\end{tabular}

- усвідомлення завдання;

- оцінка обстановки;

- прийняття рішення;

- деталізація рішення та його документальне оформлення (розроблення планувальних документів)

- побудова службового порядку мобільного підрозділу відповідно до прийнятого рішення;

- постановка завдань;

- організація (уточнення) взаємодії;

- організація (уточнення) управління, у т.ч. створення структури управління;

- організація всебічного забезпечення;

- організація роботи з персоналом

- моніторинг дій мобільного підрозділу;

- зіставлення реально досягнутих результатів із запланованим;

- виявлення відхилень та їх корегування (усунення)

- здійснення маршу до ділянки застосування;

- уточнення питань взаємодії 3 підрозділами, які діють на ділянці застосування мобільних груп;

- організація служби мобільних груп відповідно до план-графіку, віддача наказу на охорону державного кордону;

- коригування план-графіку несення служби відповідно до розвитку обстановки та отриманої інформації;

- здійснення маршу до місця постійної дислокації
Методика роботи штабу прикордонного загону з організації використання мобільного підрозділу повинна передбачати такі етапи: планування

оперативно-службової діяльності; організація оперативно-службової діяльності мобільного підрозділу; контроль готовності до оперативнослужбової діяльності; практична робота на визначеній ділянці. Розглянемо зазначені етапи детальніше. Планування оперативно-службової діяльності - це комплекс заходів із вироблення рішення на використання мобільного підрозділу, способів та послідовності його дій для досягнення визначеної мети.

Під час проведення цього етапу аналізуються результати роботи офіцерів оперативно-розшукових підрозділів 3 метою оперативного забезпечення майбутніх дій мобільних груп для отримання інформації про основні напрями протиправної діяльності та уточнення напрямів зосередження основних зусиль.

Основними завданнями, що покладаються на групу 3 організації оперативно-службової діяльності є: визначення основних загроз, що матимуть місце на ділянці відповідальності; визначення спроможності 
мобільного підрозділу виконувати завдання оперативно-службової діяльності; визначення порядку застосування мобільного підрозділу в охороні державного кордону, основні способи застосування та найбільш ймовірні райони дій сил та засобів; визначення основних питань взаємодіі.

При визначенні порядку застосування мобільного підрозділу опрацьовуються основні форми та способи дій щодо забезпечення рішення начальника відповідного рівня управління на його застосування на державному кордоні та у пунктах пропуску. Як правило обираються найбільш оперативні напрямки та найбільші пункти пропуску.

Основою визначення порядку застосування $є$ рішення начальника, пропозиції штабу та начальника мобільного підрозділу щодо використання сил та засобів в охороні кордону.

Під час організації оперативнослужбової діяльності мобільного підрозділу проводиться комплекс заходів 3 організації виконання рішення на використання мобільного підрозділу.

Зокрема, організуючі службові дії мобільного підрозділу, штаб повинен визначити: кількість і склад мобільних груп (патрулів), ділянки i райони проведення спеціальних заходів, а також кількість і склад інших нарядів для забезпечення виконання поставлених завдань; місця i час несення служби; необхідну техніку та засоби посилення; кого призначити в чергові сили та резерв (для заміни чергових сил на випадок їх застосування в охороні кордону); з ким і коли уточнити взаємодію; де, в який час і службу яких нарядів перевірити.

Завдання мобільним підрозділам щодо виконання заходів 3 охорони кордону доводяться особисто начальником штабу прикордонного загону, або за його дорученням заступниками та іншими посадовими особами з виїздом до підрозділу, шляхом передачі по технічних засобах зв'язку або доставки службових документів офіцерами управління. 3 цією метою штабом прикордонного загону відпрацьовується розпорядження, в якому вказують: необхідні дані обстановки; відомості про порушників законодавства 3 прикордонних питань; напрямки (райони) зосередження основних зусиль; порядок та способи виконання завдань; завдання мобільному підрозділу (мобільній групі, окремим нарядам); порядок організації управління та взаємодії; питання всебічного забезпечення; порядок подання донесень; основні заходи щодо підготовки до виконання завдань; час готовності до виконання отриманих завдань.

Контроль готовності до оперативнослужбової діяльності - це функція органів управління прикордонного загону, процес забезпечення досягнення мети за допомогою оцінювання та аналізу результатів дій підпорядкованих підрозділів, оперативне втручання та корегування виконання ними завдань оперативно-службової діяльності.

Основною метою контролю $\epsilon$ забезпечення точного і своєчасного виконання вимог керівних документів, що регламентують оперативно-службову діяльність, підтримання готовності підпорядкованих підрозділів до дій, а також рішень, наказів і розпоряджень.

Основним завданням контролю $\epsilon$ виявлення та усунення недоліків і помилок посадових осіб. Контроль обов'язково поєднується 3 наданням допомоги підлеглим у вирішенні завдань оперативно-службової діяльності, підвищенням професійного рівня персоналу. Контроль та надання допомоги мобільним підрозділам організовується та здійснюється начальниками (керівниками) усіх ступенів, органами управління, зміною центру управління службою i посадовими особами прикордонного загону в межах наданих їм повноважень.

Ефективність контролю досягається: систематичністю, цілеспрямованістю, своєчасністю, всебічністю, глибиною, об'єктивністю та результативністю проведеної перевірки.

У першу чергу контролюються: своєчасність отримання підрозділом наказів i розпоряджень; відповідність рішень, прийнятих підлеглими, задуму на здійснення оперативнослужбової діяльності, отриманим завданням; своєчасність і якість виконання підрозділами заходів 3 підготовки до виконання поставлених завдань у встановлені терміни; організація взаємодії та всебічного забезпечення; готовність системи управління підрозділами; організація і виконання заходів 3 готовності мобільних підрозділів до дій.

Кінцевою метою контролю $є$ фактичне поліпшення стану справ у підпорядкованих підрозділах, усунення у стислі терміни виявлених недоліків, запобігання порушенням чинного законодавства i правопорядку, виявлення безвідповідальності, фактів низької виконавської дисципліни.

3 метою контролю начальник мобільного підрозділу планує та здійснює перевірки 
особисто або за дорученням старшого начальника, із залученням до їх проведення своїх заступників. Кількість перевірок начальником мобільного підрозділу визначається, виходячи з умов наявності сил і засобів та спрямовуються на забезпечення належного рівня їх готовності до дій.

Планування перевірок полягає у визначенні кількості перевірок на тиждень, 3 них: кількість перевірок нарядів вночі та вдень; визначення основного завдання перевірки та способу іiі здійснення; визначення місць та часу перевірки нарядів; визначення осіб, призначених для перевірок.

У ході практичної роботи на місчевості відбувається: уточнення напрямків зосередження основних зусиль; уточнення місць та маршрутів несення служби; визначення заходів маскування під час виконання завдань; уточнення місць розміщення та відпочинку; уточнення питань взаємодії з підрозділами, які діють на ділянці застосування мобільних груп (узгодження дій по завданням, рубежам та часу, визначення основних сигналів взаємодії та оповіщення); уточнення порядку обміну інформацією.

Крім того проводиться організація служби мобільних груп відповідно до планграфіку, віддача наказу на охорону державного кордону, коригування планграфіку несення служби відповідно до розвитку обстановки та отриманої інформації та здійснення маршу до місця постійної дислокації.

В інтересах забезпечення раптовості, ефективності та маскування дій мобільних підрозділів на етапі іiі безпосередньої підготовки до застосування залучається обмежена кількість посадових осіб. 3 метою введення противника в оману стосовно місця, часу та напрямків застосування підрозділів для виконання завдань 3 охорони державного кордону проводяться відволікаючі дії прикордонних нарядів прикордонних підрозділів.

Висновок. Таким чином, у статті на основі проведеного аналізу існуючих керівних документів та досвіду організації використання мобільних підрозділів, визначено методику роботи штабу прикордонного загону 3 організації використання мобільного підрозділу в оперативно-службовій діяльності яка дає змогу перейти до обгрунтування рекомендацій щодо управління службою мобільного підрозділу.

\section{СПИСОК ВИКОРИСТАНОЇ ЛІТЕРАТУРИ}

1. Наказ Адміністрації Державної прикордонної служби України від 30.12.05 № 1039 "Про затвердження Тимчасової інструкції про застосування мобільних підрозділів Державної прикордонної служби України", - Київ : АДПСУ, 2005.

2. Наказ Адміністрації Державної прикордонної служби України від 23 березня 2010 року № 209 "Про затвердження Інструкції про організацію та здійснення планування в Державній прикордонній службі України" - Київ : АДПСУ, 2010.

3. Потомський Ю. В. Методичні рекомендації штабам органів (підрозділів) охорони з організації роботи під час ускладнення обстановки. Київ. 2006.

4. Бойовий Статут Сухопутних військ Збройних Сил України (частина II (батальйон, рота). Затверджено наказом командувача Сухопутних військ Збройних Сил України від 29.12.10 № 574. - Київ, - 2010 $216 \mathrm{c.}$

5. Ананьїн О. В. Досвід бойових дій органів (підрозділів) Державної прикордонної служби України під час проведення антитерористичної операції: інформаційно-аналітичні матеріали. Київ : Адміністрація ДПСУ, 2015. - 55 с.

6. Ананьїн О. В. Органи (підрозділи) Державної прикордонної служби України у системі оборони (охорони) державного кордону в умовах сучасного збройного конфлікту: інформаційно-аналітичні матеріали. - Київ : Адміністрація ДПСУ, 2015. $25 \mathrm{c}$.

Стаття надійшла до редакції 08.11.2017

Крутов В. В. д.ю.н., профессор ${ }^{1}$;

Яичко О. М. ${ }^{2}$

1 - Украинский союз промышленников и предпринимателей, Киев;

2 - Национальная академия Государственной пограничной службы Украины имени Богдана Хмельницкого, Хмельницкий

Методика работы штаба пограничного отряда по организации использования мобильного подразделения

Резюме. В статье, на основе проведенного анализа существующей нормативно-правовой базы по организации и управлению оперативно-служебной деятельности мобильных подразделений и опыта работы штабов пограничных отрядов, изложены предложения к методике работы штаба пограничного отряда по организации использования мобильного подразделения.

Ключевые слова: мобильное подразделение, методика, анализ руководящих документов и опыта. 


\section{Krutov, Ds. M, professor ${ }^{1}$;}

O. Yaichko, Ph. D

1 - Ukrainian Union of industrialists and entrepreneurs, Kyiv;

${ }^{2}$ - National academy of the State Border Guard Service of Ukraine named after Bogdan Khmelnitsky, Khmelnitsky

Methodology of the border guard detachment headquarters work on the organization of mobile unit's deployment

Resume. The proposals to the methodology of the border detachment headquarters work on the organization of the mobile unit's deployment have been outlined in the article. These proposals are based on the analysis of the existing legal and regulatory framework for organization and management of mobile units operational and service activities and the work experience of the border detachment headquarters.

Keywords: mobile unit, methodology, analysis of management documents and experience. 